\title{
A comprehensive analysis to understand the mechanism of action of balneotherapy: why, how, and where they can be used? Evidence from in vitro studies performed on human and animal samples
}

\author{
Sara Cheleschi ${ }^{1,2} \cdot$ Ines Gallo $^{1} \cdot$ Sara Tenti ${ }^{1}$ \\ Received: 22 November 2019 / Revised: 21 February 2020 / Accepted: 26 February 2020 / Published online: 21 March 2020 \\ (C) ISB 2020
}

\begin{abstract}
Balneotherapy (BT) is one of the most commonly used complementary therapies for many pathological conditions. Its beneficial effects are related to physical and chemical factors, but the exact mechanism of action is not fully understood. Recently, there has been an increased interest in the use of preclinical models to investigate the influence of BT on inflammation, immunity, and cartilage and bone metabolism. The objective of this comprehensive analysis was to summarize the current knowledge about the in vitro studies in BT and to revise the obtained results on the biological effects of mineral waters. Special attention has been paid to the main rheumatological and dermatological conditions, and to the regulation of the immune response. The objective of this review was to summarize the in vitro studies, on human and animal samples, investigating the biological effects of BT. In particular, we analyzed the properties of a thermal water, as a whole, of an inorganic molecule, such as hydrogen sulfide in different cell cultures (keratinocytes, synoviocytes, chondrocytes, and peripheral blood cells), or of the organic component. The results corroborated the scientific value of in vitro studies in demonstrating the anti-inflammatory, antioxidant, chondroprotective, and immunosuppressive role of BT at the cellular level. However, the validity of the cell culture model is limited by several sources of bias, as the differences in experimental procedures, the high heterogeneity among the available researches, and the difficulties in considering all the chemical and physical factors of BT. We would like to stimulate the scientific community to standardize the experimental procedures and enhance in vitro research in the field of BT.
\end{abstract}

Keywords Balneotherapy $\cdot$ Mineral waters $\cdot$ Hydrogen sulfide $\cdot$ Cell cultures $\cdot$ Keratinocytes $\cdot$ Chondrocytes

\section{Introduction}

Balneotherapy (BT) is a complementary therapy that generally employs mineral and/or thermal waters from natural springs, peloids (mud), and other traditional remedies, for the treatment of different pathological conditions (dermatological, rheumatological, gastroenterological conditions, pulmonary diseases, cardiovascular, gynecological, metabolic, neurological, psychiatric, and endocrine disorders) (Contoli

Sara Cheleschi

saracheleschi@hotmail.com

1 Department of Medicine, Surgery and Neuroscience, Rheumatology Unit, Azienda Ospedaliera Universitaria Senese, Policlinico Le Scotte, 53100 Siena, Italy

2 Department of Medicine, Surgery and Neuroscience, Rheumatology Unit, University of Siena, Policlinico Le Scotte, Viale Bracci 1, 53100 Siena, Italy et al. 2013; Fioravanti et al. 2017; Forestier et al. 2017; Guidelli et al. 2012; Katz et al. 2012; Matsumoto 2018; Naumann and Sadaghiani 2014; Tenti et al. 2015).

A large number of clinical studies have reported the beneficial effects of this approach for the prevention, treatment, and rehabilitation of various rheumatic disorders, such as osteoarthritis (OA) (Espejo-Antúnez et al. 2013; Fioravanti et al. 2015; Forestier et al. 2010; Király et al. 2019; Masiero 2008; Masiero et al. 2018), fibromyalgia (FM) (Fioravanti et al. 2018; Naumann and Sadaghiani 2014; Ozkurt et al. 2012), low-back pain (Karagülle and Karagülle 2015; Tefner et al. 2012; Yücesoy et al. 2019), rheumatoid arthritis (RA) (Brosseau et al. 2002; Santos et al. 2016), and other chronic inflammatory rheumatic diseases (Cozzi et al. 2018). Current results support a positive effects of $\mathrm{BT}$ on pain, function, and quality of life with a significant reduction in symptomatic drug consumption (Antonelli et al. 2018; Matsumoto et al. 2017); furthermore, the clinical efficacy lasts over time, until 69 months after a cycle of treatment (Fioravanti et al. 2015; 
Forestier et al. 2010; Fortunati et al. 2016). Finally, this approach showed a favorable cost/effectiveness profile (Ciani et al. 2017).

The use of mineral waters and, in particular of the sulfurous waters, represents a useful complementary therapy in dermatological patients (Huang et al. 2018; Péter et al. 2017; Szabó 2007). Recently, growing evidence disclosed the potential therapeutic properties of BT in psoriasis and atopic or contact dermatitis (Huang et al. 2018; Péter et al. 2017).

The beneficial effects of mineral waters are related to their physical and chemical properties, such as temperature, salt composition and concentrations, osmotic pressure, and electric conductivity (Fioravanti et al. 2011; Morer et al. 2017). These particular characteristics make difficult to understand the mechanisms of action of BT and to analyze the biological role of the different components which constitute a whole mineral water (Fioravanti et al. 2011; Morer et al. 2017). Indeed, thermal waters are very sophisticated systems consisting of a mixture of different organic and inorganic compounds. Traditionally, they were classified on the basis of their inorganic composition, but, recently, their organic fraction has been demonstrated as highly bioactive, contributing to the medicinal effects of BT (Szabó and Varga 2019).

In the last years, there has been an increased interest in the use of preclinical models (animal or in vitro studies) to investigate the biological effects of BT on inflammation, immunity, and cartilage and bone metabolism.

To date, just a limited number of controlled animal studies have been carried out in this field. In particular, some authors demonstrated the anti-inflammatory, antinociceptive, antioxidant, and chondroprotective properties of BT, principally reducing cytokines and free radical production, and decreasing the mechanical hyperalgesia and edema in different murine models of arthritis or psoriasis (Abu-al-Basal 2012; Bajgai et al. 2017; Britschka et al. 2007; Cozzi et al. 2004; Tékus et al. 2018; Zivná et al. 2012). Some aspects of these studies are disputable and could represent a source of bias. Indeed, comparisons among the various studies are difficult principally because of the difference in type and length of interventions, and, in certain cases, the combinations of treatment modalities. The problem in working with animals is mainly related to economical problems, to establish a specific model for a particular disease and to find the most suitable application routine of BT or the protocol of mud treatment (Tékus et al. 2018). Furthermore, the restraint conditions at which the animals are subjected for the treatments may exert stress reactions that can influence the experimental outcomes (Scheich et al. 2017; Tékus et al. 2016).

These considerations stimulate to identify new preclinical studies employing cell culture models to avoid possible bias related to the use of animals.

The objective of this comprehensive analysis was to revisit the role of the in vitro studies in BT and to summarize the obtained results on the biological effects of mineral waters. Special attention has been paid to the main rheumatological and dermatological conditions, which take any advantage by $\mathrm{BT}$, and to the regulation of the immune response.

\section{In vitro studies on balneology: why, how, and where}

\section{Why}

In vitro research represents the starting point in biological and medical investigation, and it is conducted using components of an organism (tissues or cells) that have been isolated from their usual biological surroundings and used to emulate different aspects of human body functions; this permits a simpler, more rapid, detailed, and convenient analysis than what can be done with whole organisms (Johnson et al. 2016; Miller and Spence 2017). The myriad of in vitro experimental models offers a diverse variety of experimental approaches, which can provide empirical data potentially unobtainable from whole-animal studies, also reducing the probability of bias when animal usage tests or clinical trials are performed (Miller and Spence 2017).

In vitro studies were normally used to evaluate the effects and/or the mechanism of action of mechanical (such as hydrostatic pressure, mechanical compression, ultrasound, magnetic or electromagnetic fields) or chemical factors (cytokine, growth factors, adipokines, drugs, mineral elements, etc.) on cell or tissue morphology and metabolism (Cheleschi et al. 2015; Cheleschi et al. 2018; Cheleschi et al. 2019a; Cheleschi et al. 2019b; Collodel et al. 2013; Fioravanti et al. 2010; Kloesch et al. 2011; Marrazzo et al. 2019; Shams et al. 2018).

In vitro investigation plays a pivotal role to advance research into the physiopathology of a particular disease, and to help the development of potential therapeutic strategies (Johnson et al. 2016).

\section{How}

In recent years, lots of advancements have been made in the area of culture systems, which have enhanced functionality and stability of cells in vitro.

Tissue of human or animal origin, monodimensional or tridimensional cell cultures (for instance keratinocytes, chondrocytes, fibroblasts, polymorphonuclear cells), cell suspensions, or co-cultures can be employed. Studies on primary cells are the most used model for in vitro tests because they closely represent the tissue of origin, are not modified, and provide excellent culture systems for studying the physiological or pathological behavior of the native organ in vivo. Standardized and immortalized cell lines have been 
also developed to obtain indefinite subcultures with a high experimental repeatability and reproducibility, but without phenotypic characteristics of the in vivo tissue (Hanks et al. 1996; Miller and Spence 2017).

Each culture system presents advantages and disadvantages, and each is particularly suitable for exploring one specific aspect of cell metabolism, according to the aims of the study.

In the field of BT, tissue explants, primary cells, or immortalized lines can be used to investigate the potential biological effects of a single inorganic molecule (Carbajo and Maraver 2017; Viegas et al. 2019; Wallace and Wang 2015), or organic compounds (Gerencsér et al. 2019), or a mineral water as a whole (Fioravanti et al. 2011; Gálvez et al. 2018).

Among the inorganic molecules, which generally constitute the mineral waters, sulfur has currently been recognized as a crucial element with a wide range of functions, mainly when it was found in the form of hydrogen sulfide $\left(\mathrm{H}_{2} \mathrm{~S}\right)$ (Carbajo and Maraver 2017; Viegas et al. 2019; Wallace and Wang 2015). $\mathrm{H}_{2} \mathrm{~S}$ represents the main active molecule of sulfurous mineral-medicine waters; it is a small gaseous molecule traditionally considered as toxic gas, but, in the last years, scientific opinion has changed as more reports on its biological activity were published, and it is now considered a biologically relevant molecule (Carbajo and Maraver 2017; Wallace and Wang 2015).

$\mathrm{H}_{2} \mathrm{~S}$ is an endogenous gasotransmitter, and, as such, it can be absorbed by numerous routes; it is able to penetrate the skin and mucosae and can therefore act at the cell level both in the skin and in internal organs (Burguera et al. 2017; Carbajo and Maraver 2017).

Its exogenous and endogenous donors at high micromolar concentrations were generally employed in in vitro research to mimic physiological functions of $\mathrm{H}_{2} \mathrm{~S}$ at cellular level and to identify its potential mechanism of action (Carbajo and Maraver 2017; Wallace and Wang 2015).

Organic components of thermal waters were demonstrated to have biological effects contributing to the healing mechanisms, but their medical significance is not still fully understood (Varga 2012a). However, in a recent double-blind, randomized controlled trial on knee and hip OA patients, the organic fraction separated from the whole Szigetvár medicinal water and redissolved in tap water determined a major improvement of the studied clinical outcomes than what is observed in tap water alone (Hanzel et al. 2019). This finding explains the so-called Varga's organic hypothesis, which supports that the biological effects of thermal waters are caused by bioactive organic molecules more likely than by the inorganic salt content (Varga 2010; Varga 2012b).

However, due to the raised number and variety of organics, the only method to analyze these organic mixtures, including possible interactions, is the determination of their biological activities in different tests. The most informative results were obtained from the Comet Assay (single-cell microgel electrophoresis for DNA damage) and the Salmonella Ames mutagenicity studies with the different chemical fractions of waters and peloids. Recently, (Varga et al. 2015)) presented a new application of the Salmonella TA strains originally engineered for the Ames mutagenicity test. After the organic extracts were isolated from five Hungarian thermal spa waters, the authors found that 4 of them showed a detectable UVprotective effect in Salmonella TA bacteria, demonstrating for the first time the UV-protective property of organic matter in natural thermal water samples.

However, it is plausible to think that the efficacy of a thermal mineral water is probably related to a complex relationship among a number of different chemical components (Fioravanti et al. 2011; Morer et al. 2017). This consideration leads us to identify the most suitable preclinical model to better investigate the mechanism of action of a mineral water as a whole.

\section{Where}

\section{In vitro studies on keratinocyte investigating the effects of BT on skin diseases}

Gobbi et al. in 2009 and Mirandola et al. in 2011 (Gobbi et al. 2009; Mirandola et al. 2011) demonstrated the antiinflammatory effect of exogenous source of $\mathrm{H}_{2} \mathrm{~S}$, natrium hydrogen sulfide, a fast-dissolving salt (NaHS), in normal skinderived immortalized human keratinocyte cultures. After incubation of the cells with NaHS ( $400 \mathrm{mM}$, for $6,12,18,24 \mathrm{~h}$ ) in the presence of a specific mitogen-activated protein kinase (MAPK)/extracellular signal-regulated kinase (ERK) inhibitors, a reduced secretion of interleukin (IL)-8, IL-17, and IL22 , as well as a decreased cell proliferation and adhesion, through a downregulation of adhesion molecule expression, was observed, by reducing MAPK/ERK signaling phosphorylation (Table 1).

Furthermore, a group of investigators performed three different in vitro studies in order to evaluate the potential beneficial effects of Comano spa's water (Trentino, Italy), a thermal hypotonic water containing various electrolytes as sodium, calcium, and bicarbonate, on the clinical manifestations of psoriasis (Chiarini et al. 2006a; Chiarini et al. 2006b; Dal Pra et al. 2007). Human psoriatic keratinocytes were incubated with different concentrations of Comano water (totally or partially dissolved in the culture medium) for an experimental period from 3 to 15 days and, then, the medium was collected and the cells processed for further analyses. The results demonstrated a reduced release and expression of vascular endothelial growth factor (VEGF) A, IL-8, IL-6, and cytokeratin (CK)-16 (a marker associated with keratinocyte psoriatic phenotype) in cells treated with all the studied concentrations of mineral water (Table 1). 


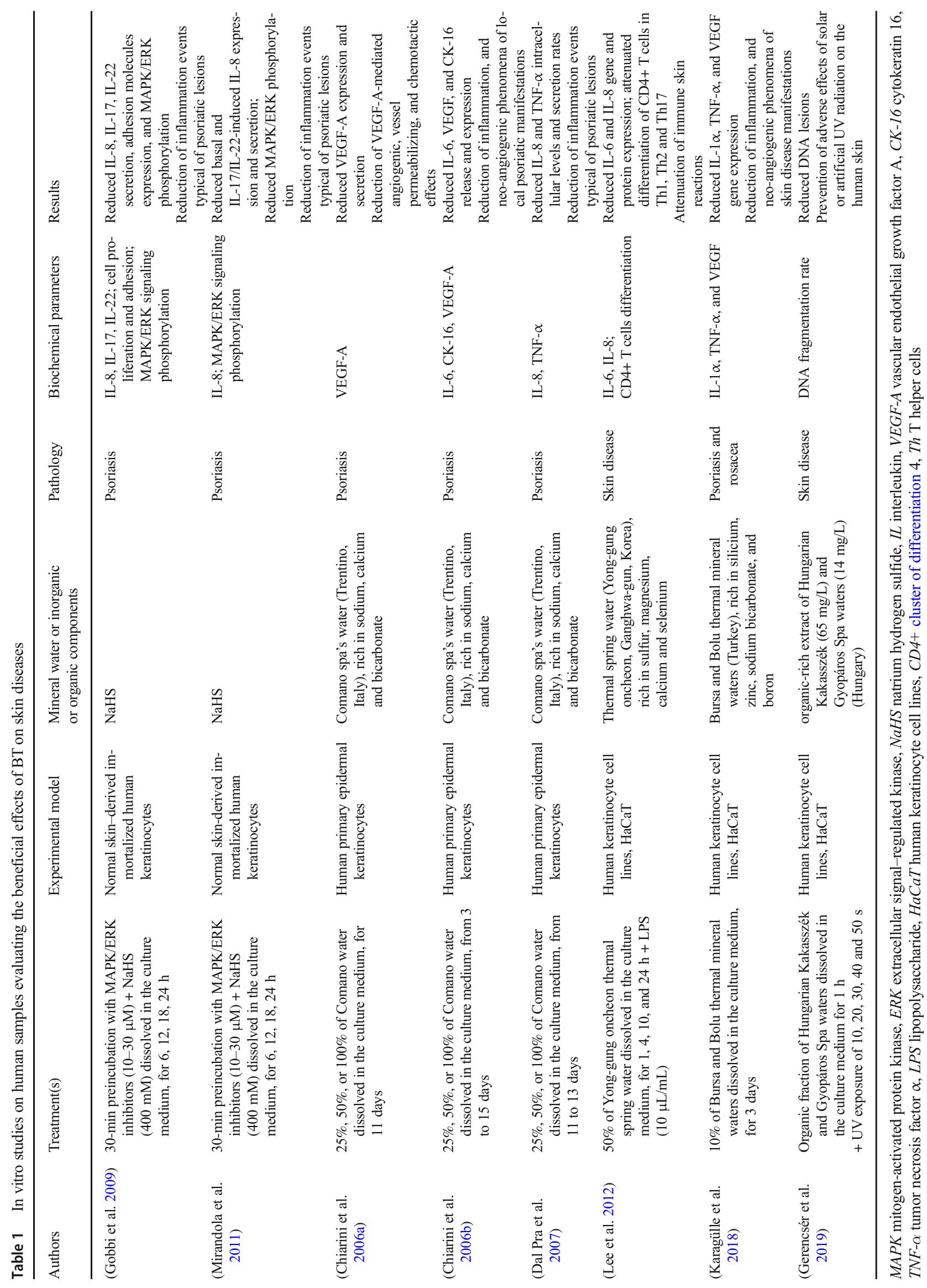


Human keratinocyte cell lines, HaCaT, were used by Lee et al. (2012) to analyze the immunomodulatory or antiinflammatory effects of a thermal spring water, from the Yong-gung oncheon (Ganghwa-gun, Korea), rich in sulfur, magnesium, calcium, and selenium, against the typical signs of inflammatory skin diseases. The Authors showed a suppressed expression of inflammatory cytokines (IL-6, IL-8) and an attenuated differentiation process of subsets of CD4+ T cells, into Th1, Th2, and Th17 cells, after 1, 4, 10, or $24 \mathrm{~h}$ of treatment with $50 \%$ concentration of spa spring water (Table 1).

$\mathrm{HaCaT}$ lines were also employed to an in vitro test of Bursa and Bolu waters, two traditional and historical thermal mineral waters of Turkey (Karagülle et al. 2018). Three days of incubation of the cells with $10 \%$ concentration of the two tested waters significantly reduced the gene expression of IL- $1 \alpha$, tumor necrosis factor (TNF)- $\alpha$, and VEGF. The obtained results proved the anti-inflammatory and angiogenic properties of these spa waters in skin diseases such as rosacea and psoriasis (Table 1).

Recently, the effect of Hungarian Kakasszék spa (medicinal) water (KSZ) and Gyopáros spa water (GYP), containing a high variability of organic components, in preventing the adverse effects of solar or artificial UV radiation on the human skin was analyzed (Gerencsér et al. 2019). The organic fractions of each water were prepared using a procedure involving isolation of organics on Amberlite XAD macroreticular adsorbent resins. After $1 \mathrm{~h}$ incubation of $\mathrm{HaCaT}$ cells with organic-rich extract of KSZ or GYP with or without different timings of UV irradiation exposure, GYP isolate incubation resulted to be able to prevent DNA lesions of keratinocytes induced by UV exposure (Table 1).

\section{In vitro studies on fibroblast-like synoviocytes, chondrocytes, and osteoblasts investigating the effects of BT on joint disorders}

Fibroblast-like synoviocyte cultures, derived from RA and OA patients, and chondrocyte cell line C-28/I2 were employed by Kloesch et al. $(2010 ; 2012 a ; b)$ to study the molecular mechanism of action of $\mathrm{H}_{2} \mathrm{~S}$, by using its exogenous source, NaHS. These cells constitutively expressed and secreted large quantities of IL- 6 and IL-8. Furthermore, their treatment with different concentrations of NaHS $(0.030$ $1 \mathrm{mM}$, for a maximum of $12 \mathrm{~h}$ ) transiently reduced the constitutive expression of IL- 6 and IL- 8 and the activation of MAPK/ERK signaling, as well as those induced by IL-1 $\beta$ $(5 \mathrm{ng} / \mathrm{mL}, 1 \mathrm{~h})$ (Kloesch et al. 2010, 2012a, b). On the contrary, high concentration of NaHS (above $0.5 \mathrm{mM}$ ) demonstrated opposite effects both on the expression of cytokines and cyclooxygenase (COX)-2 and on the activation of MAPK/ERK proteins (Kloesch et al. 2012a, b). These results explained the beneficial effect of $\mathrm{H}_{2} \mathrm{~S}$ on inflammatory processes involved in the pathophysiology of RA and OA, underling the importance of sulfur baths as possible therapeutic effect in such kind of diseases, taking into consideration $\mathrm{H}_{2} \mathrm{~S}$ exposure in terms of timing and concentration (Table 2).

Growing evidence underlines the relevance of $\mathrm{H}_{2} \mathrm{~S}$ and its exogenous sources as anti-inflammatory and anti-catabolic agents in human OA chondrocyte and synoviocyte cultures (Table 2).

In 2012, (Fox et al. 2012) studied the ability of human primary chondrocytes and mesenchymal progenitor cells to synthesize $\mathrm{H}_{2} \mathrm{~S}$ in response to pro-inflammatory mediators stimulation (IL-1 $\beta$, IL-6, TNF- $\alpha$, and lipopolysaccharide (LPS)), and their response to the exogenous slow-releasing $\mathrm{H}_{2} \mathrm{~S}$ source (GYY4137). Endogenous $\mathrm{H}_{2} \mathrm{~S}$ produced by the cells and the treatment with different concentrations of GYY4137 (50-500 mol/L for $18 \mathrm{~h}$ ) significantly reduced cell death and oxidant-induced mitochondrial dysfunction, caused by inflammatory cytokines, via protein kinase B $(\mathrm{Akt}) /$ phosphoinositide 3-kinase (PI3K)-dependent signaling.

Li et al. (2013) assessed the effect of GYY4137 (0.1$0.5 \mathrm{mM})$ on LPS $(10 \mu \mathrm{g} / \mathrm{mL})$-caused release of inflammatory mediators from human arthritis synoviocytes and articular chondrocytes. After $18 \mathrm{~h}$ of treatment, GYY4137 demonstrated a prominent anti-inflammatory effect decreasing the production of nitrite $\left(\mathrm{NO}_{2}{ }^{-}\right)$, prostaglandin E2 (PGE2), TNF- $\alpha$, and IL- 6 from both cell types, reducing the levels and catalytic activity of inducible nitric oxide synthase (iNOS) and COX-2, and limiting nuclear factor (NF)- $\mathrm{KB}$ activation induced by LPS.

Equivalent results were obtained in a study on human OA chondrocytes stimulated with IL- $1 \beta$, used as prototype proinflammatory cytokine to reproduce the "OA-like effect" (Burguera et al. 2014). The results of the research proved the ability of NaHS and GYY4137 (0.05-1 mM, for 24 or $48 \mathrm{~h}$ ) to significantly limited nitric oxide (NO), PGE2, and IL-6 released by the cells and at protein level, as well as the gene expression of NOS2, COX-2, prostaglandin E synthase (PTGES), IL-6, and NF-KB nuclear translocation activated by IL- $1 \beta$ stimulus $(5 \mathrm{ng} / \mathrm{mL})$. Furthermore, these Authors firstly demonstrated the anti-catabolic activity of these compounds through the downregulation of metalloproteinase (MMP)-13 in the supernatant and at protein level.

These data were confirmed by Ha et al. (2015) in a study on human OA chondrocyte cultures treated with NaHS $(0.06$ $1.5 \mathrm{mM})$ in the presence or not of IL-1 $\beta(10 \mathrm{ng} / \mathrm{mL})$ stimulus for $24 \mathrm{~h}$. The compound markedly reversed the effects of IL$1 \beta$ on the gene expression of COX-2, MMP-13, and NOS and on their production in the supernatant. In addition, NaHS inhibited the activation of the $\mathrm{ERK} / \mathrm{I} \kappa \mathrm{B} \alpha / \mathrm{NF}-\mathrm{kB}$ pathway which was induced by IL- $1 \beta$.

In the same year, Sieghart et al. (2015) investigated the effects NaHS $(0.06-1 \mathrm{mmol} / \mathrm{L})$, in OA fibroblast-like synoviocytes stimulated with IL-1 $\beta(10 \mathrm{ng} / \mathrm{mL})$. The 


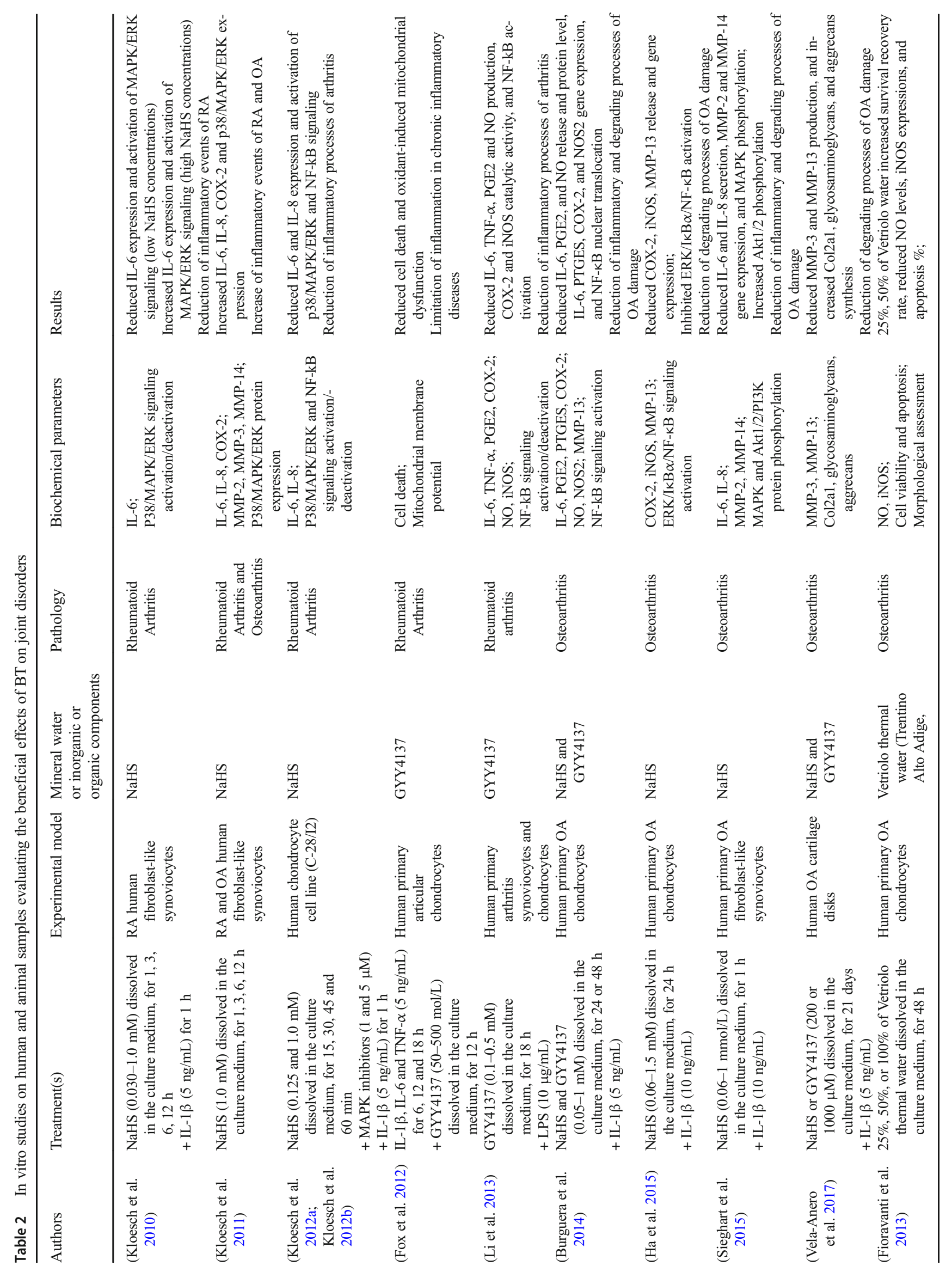




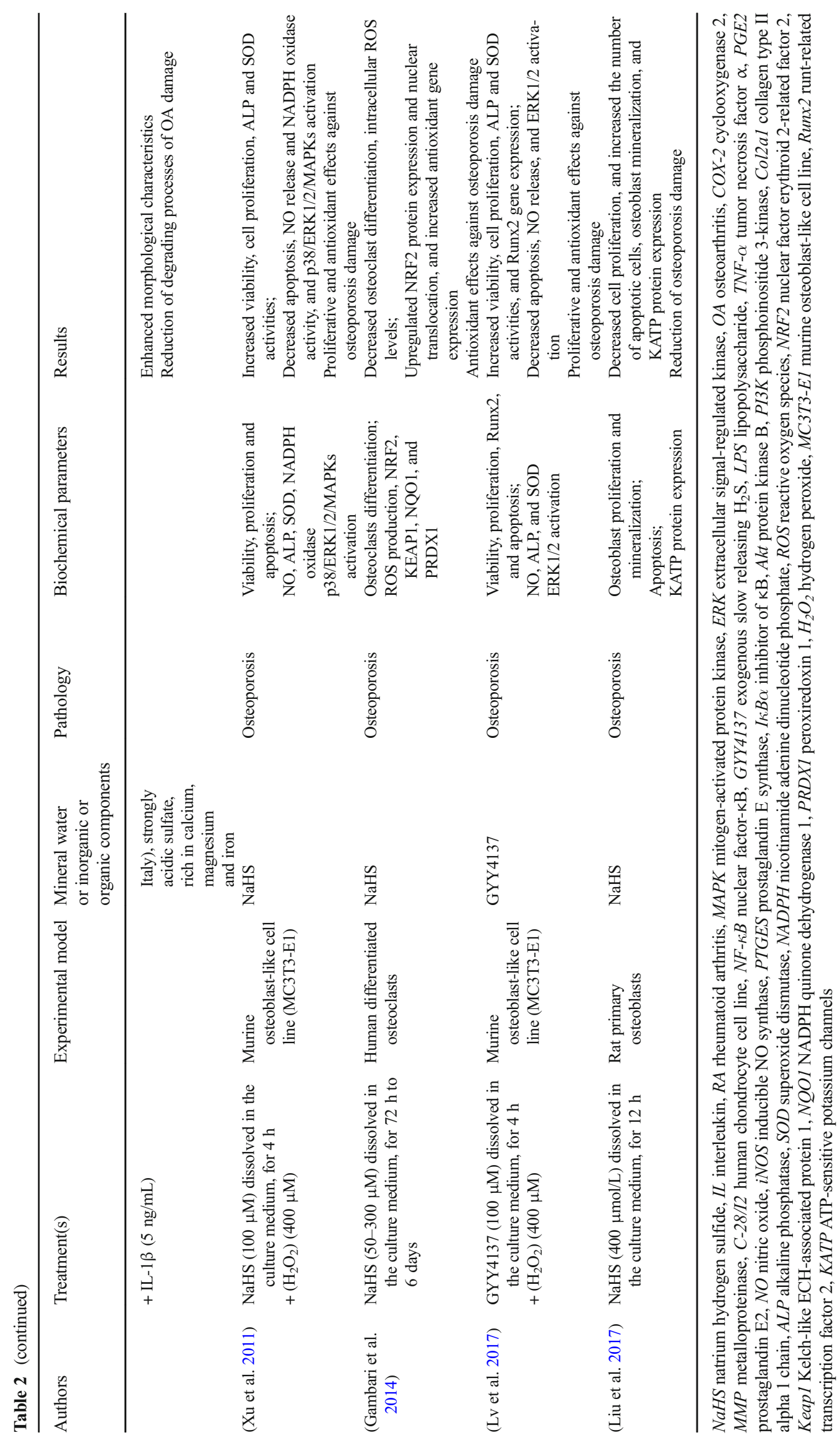


Authors observed that $1 \mathrm{~h}$ of NaHS treatment reduced spontaneous and IL- $1 \beta$-induced secretion of IL- 6 , IL- 8 , and RANTES, the expression of MMP-2 and MMP-14, and the phosphorylation of several MAPK proteins. On the contrary, sulfide source increased the phosphorylation of pro-survival factor Akt1/2, suggesting the ability of $\mathrm{H}_{2} \mathrm{~S}$ to partially antagonize IL- $1 \beta$ stimulation via selective manipulation of the MAPK and the PI3K/Akt pathways.

Later, a similar research was conducted on OA cartilage extracts co-cultured with IL- $1 \beta(5 \mathrm{ng} / \mathrm{mL})$ and NaHS or GYY4137 $(200$ or $1000 \mu \mathrm{M})$ for 21 days (Vela-Anero et al. 2017). At the end of the treatment, the histological and immunohistochemical analyses of the samples demonstrated a reduction of catabolic processes and a stimulation of cell anabolism. Indeed, a decrease in glycosaminoglycan destruction and MMP- 3 and MMP-13 production caused by IL- $1 \beta$, in addition to an increased synthesis of collagen type II alpha 1 chain (Col2a1) and aggrecans, was observed in NaHS or GYY4137-treated cells.

All these findings provide new information about the antiinflammatory, antioxidant, and anti-catabolic properties of $\mathrm{H}_{2} \mathrm{~S}$ and of its exogenous sources in in vitro cultures. $\mathrm{H}_{2} \mathrm{~S}$ seems to act as a chondroprotective agent by regulating relevant factors implicated in OA pathogenesis and progression, and counteracting IL-1 $\beta$ pro-inflammatory signals that lead to cartilage destruction.

Furthermore, in 2013, Fioravanti et al. (2013) studied the potential beneficial effect of Vetriolo thermal water (Trentino Alto Adige, Italy), a highly mineralized water, strongly acidic sulfate $\left(\mathrm{SO}_{4}{ }^{-}\right)$, rich in calcium, magnesium, and iron, in human OA chondrocytes cultivated in the presence of IL-1 $\beta$ $(5 \mathrm{ng} / \mathrm{mL})$. To better appreciate the properties of mineral water, it has been tested at different concentrations $(100 \%, 50 \%$, $25 \%$ ), directly dissolved in the culture medium. The Authors showed a significant survival recovery rate, a reduction in $\mathrm{NO}$ levels, and expression of iNOS, as well as an enhancement of morphological characteristics of the cells, altered by IL- $1 \beta$, in chondrocytes treated with $50 \%$ and $25 \%$ Vetriolo thermal water; these data demonstrated the chondroprotective role of Vetriolo mineral water.

On bone-derived cells, only a limited number of in vitro studies were performed to investigate the properties of exogenous sources of $\mathrm{H}_{2} \mathrm{~S}$ (Table 2).

Firstly, Xu et al. (2011) showed the proliferative, antioxidant, and anti-inflammatory effects of $4 \mathrm{~h}$ of treatment with $\mathrm{H}_{2} \mathrm{~S}$ donor, NaHS $(100 \mu \mathrm{M})$, in hydrogen peroxide $\left(\mathrm{H}_{2} \mathrm{O}_{2}\right)$ $(400 \mu \mathrm{M})$-stimulated murine osteoblast-like cell line. The Authors observed an increased cell viability, cell proliferation (by enhancing alkaline phosphatase activity), and reduced apoptosis, caused by $\mathrm{H}_{2} \mathrm{O}_{2}$, after NaHS incubation. Furthermore, the $\mathrm{H}_{2} \mathrm{~S}$ source increased superoxide dismutase activity, while it decreased reactive oxygen species (ROS) production, nicotinamide adenine dinucleotide phosphate (NADPH) oxidase activity, and NO and TNF- $\alpha$ release, probably via p38 and ERK1/2 MAPKs. These results were later confirmed by Lv et al. (2017), in an analogous experimental study, examining the effect of GYY4137 $(100 \mu \mathrm{M})$ added at the culture medium for $4 \mathrm{~h}$ in the presence of $\mathrm{H}_{2} \mathrm{O}_{2}(400 \mu \mathrm{M})$.

These findings are in agreement with what is observed in a research performed on human differentiated osteoclasts (Gambari et al. 2014). After an incubation period ranging from $72 \mathrm{~h}$ to 6 days in presence of NaHS $(50-300 \mu \mathrm{M})$, Gambari et al. (2014) found a significant dose-dependent decrease in osteoclast differentiation and intracellular ROS levels, and an upregulation of nuclear factor erythroid 2related factor 2 (NRF2) activity, related to an increased transcription of the downstream antioxidant genes. Thus, the Authors suggested the key role of NRF2 as a possible mediator of inhibitory effects of NaHS.

In 2017, Liu et al. (2017) pretreated rat primary osteoblast cultures with $400 \mu \mathrm{mol} / \mathrm{L}$ NaHS for $30 \mathrm{~min}$, followed by an incubation in DMEM, with high glucose concentration (HG), for $12 \mathrm{~h}$, before the analysis of cell proliferation, apoptosis, and mineralization. NaHS significantly prevented osteoblast injury induced by $\mathrm{HG}$, through decreasing the rate of cell proliferation, increasing the number of apoptotic cells, and blocking the HG-induced osteoblast mineralization inhibition, via activating ATP-sensitive potassium (KATP) channels.

\section{In vitro studies on lymphocytes, neutrophils, and eosinophils investigating the effects of BT on immune response}

The protective effects of $\mathrm{H}_{2} \mathrm{~S}$ and of its exogenous sources on cellular immune response was firstly investigated by Rinaldi et al. (2006) in a study on purified human neutrophils, eosinophils, or lymphocytes which were treated with NaHS at concentrations ranging from 0.23 to $3.66 \mathrm{mM}$ for $24 \mathrm{~h}$. The Authors found an increased short-term survival of neutrophils delaying the onset of apoptosis, while no changes in lymphocytes or eosinophils were observed. The pro-survival effect of NaHS was due to its inhibitory activity on caspase-3 cleavage and p38/MAPK phosphorylation at the protein level (Table 3).

A similar experimental protocol was performed, 1 year later, by Mirandola et al. (2007) in human purified peripheral blood lymphocytes. The cells were incubated with different concentrations of NaHS (from 0.20 to $4.0 \mathrm{mM}$ ), for a time period of $24 \mathrm{~h}$, to examine its role in regulating cell death and cytotoxicity, and its anti-inflammatory properties. At the end of the treatment, a dramatically decreased proliferation of surviving lymphocyte subsets, CD8+ T and NK cells, as well as a reduced IL-2 production, induced in response to mitogens, were observed (Table 3).

Also, Sulen et al. (2016) investigated the ability of $\mathrm{H}_{2} \mathrm{~S}$ sources to regulated the activation of signaling transduction pathways implicated in immune response. Human peripheral blood mononuclear cells (PBMCs) isolated from healthy 
donors were stimulated with $\mathrm{NaHS}$ at concentrations of 10 , 100 , or $1000 \mu \mathrm{M}$ for $10 \mathrm{~min}$, and the phosphorylation of $\mathrm{p} 38 /$ MAPK, NF-kB p65, AKT, and cAMP response elementbinding protein (CREB) was analyzed with flow and mass cytometry. NaHS induced phosphorylation of p38, AKT, and CREB, but not NF- $\mathrm{BB}$. These results provided a description of a NaHS-induced signal transduction pathway in human primary immune cells that may have relevance for the role of sulfides in inflammation (Table 3).

Furthermore, $\mathrm{H}_{2} \mathrm{~S}$ donors were used to examine their role in mediating the immune response in inflammatory bowel diseases. At this regard, nanomolar levels of $\mathrm{Na}_{2} \mathrm{~S}$ and GYY4137 (50-500 nM) were employed to treat primary mouse T lymphocytes (CD3+) and OT-II CD4+ T cells at time points of 4,10 , and 24 h to establish whether endogenous $\mathrm{H}_{2} \mathrm{~S}$ production is required for $\mathrm{T}$ cell activation, in mediating inflammatory response in such kind of diseases (Miller et al. 2012). $\mathrm{H}_{2} \mathrm{~S}$ donors enhanced $\mathrm{T}$ cell activation assessed by CD69 expression, IL-2 expression, and CD25 levels, with a maximum capacity at $300 \mathrm{nM}$. Besides, activation increased the capacity of $\mathrm{T}$ cells to synthesize endogenous amounts of $\mathrm{H}_{2} \mathrm{~S}$ via increased expression of cystathionine $\gamma$-lyase and cystathionine $\beta$-synthase. These findings lead to define $\mathrm{H}_{2} \mathrm{~S}$ as an endogenous and exogenous immunomodulatory molecule in T cells signal (Table 3 ).

The proliferative activity of $\mathrm{H}_{2} \mathrm{~S}$ donors was also demonstrated in experiments carried out on peripheral blood lymphocytes isolated from patients with systemic lupus erythematosus (Han et al. 2013). Various concentrations of NaHS $(0.25$, $0.5,1,2,4$, and $8 \mathrm{mM})$ and GYY4137 (200, 400, 800, $1600 \mu \mathrm{M}$ ) were added to the culture medium of the cells for different time points in order to evaluate the cell viability, cell cycle distribution, and expression of proteins involved in pathological pathways regulating autoimmune response. $\mathrm{H}_{2} \mathrm{~S}$ donors inhibited the abnormal activation and proliferation of lupus lymphocytes through the AKT/GSK3 $\beta$ pathway (Table 3).

Another in vitro study has been performed in activated human neutrophils isolated from blood of healthy donors, and treated with increasing amounts of the sulfurous thermal water of Acqui Terme, Piemonte, Italy, for $15 \mathrm{~min}$ (Braga et al. 2008). The cells were stimulated with N-formyl-methionylleucyl-phenylalanine and phorbol-12-myristate-13-acetate before and after incubation with sulfurous water, then the luminol-amplified chemiluminescence methodology was used to investigate ROS and reactive nitrogen species (RNS) release. The results showed that this mineral water significantly reduced the luminol-amplified chemiluminescence induced by the stimulus, on average from 0.94 to $15.5 \mu \mathrm{g} / \mathrm{mL}$ of HS (Table 3).

The same Authors performed a similar experiment treating neutrophils for $15 \mathrm{~min}$ with different concentrations of the above mentioned sulfurous water or NaHS (Braga et al.
2010); elastase release was evaluated by spectrofluorimetry, and elastolytic activity of the cells was determined by measuring the diameter of the area of elastinolysis on elastine-agarose gel plates. Sulfurous water, at concentrations ranging from 4.5 to $18 \mathrm{mg} / \mathrm{mL}$, and $\mathrm{NaHS}$, from 2.2 to $18 \mathrm{mg} / \mathrm{mL}$, significantly inhibited elastase release but did not show any direct elastolytic activity. This finding revealed the possible contribution of sulfurous water in controlling the inflammatory processes of upper and lower airway diseases (Table 3).

In 2013, Prandelli et al. (2013) used human primary monocytes to test the beneficial effects of Sirmione thermal water (Lombardia, Italy), very rich in sodium chloride, bromide, and iodide, and of NaHS at concentration of $2.5 \mathrm{mM}$. Thermal water or NaHS was added to the culture medium of the cells for $24 \mathrm{~h}$ in the presence or not of $100 \mathrm{ng} / \mathrm{mL}$ of LPS, then the release of pro-inflammatory cytokines and the formation of ROS were evaluated. NaHS efficiently blocked the production of TNF- $\alpha$, IL-1 $\beta$, IL-6, IL-12, CXCL8, and CCL5 induced by LPS, and limited ROS formation and antioxidant enzymes activity; Sirmione water did not induced the same results, but only enhanced the release of IL-10, probably due to the low concentration of S-based compounds reached at its nontoxic dilution. The Authors attested the anti-inflammatory and antioxidant properties of S-based compounds against the main manifestation of chronic inflammatory and age-related illness (Table 3).

\section{Discussion}

The objective of this review was to summarize the current available information about in vitro studies on human and animal samples investigating the biological effects of thermal mineral waters or of their organic and inorganic components, in order to identify the mechanism of action of BT in different pathological conditions.

Increasing evidence corroborated the anti-inflammatory, antioxidant, chondroprotective, and immunosuppressive role of mineral waters or $\mathrm{H}_{2} \mathrm{~S}$ on some pilot researches, despite the differences in experimental procedures, treatment modalities, and cell cultures employed.

In particular, in human psoriatic keratinocytes, $\mathrm{H}_{2} \mathrm{~S}$ donors (NaHS and GYY4137) were demonstrated to exert antiinflammatory and anti-angiogenic effects, confirming the beneficial properties of sulfur components of mineral waters on psoriatic lesions (Gobbi et al. 2009; Mirandola et al. 2011). $\mathrm{H}_{2} \mathrm{~S}$ sources seem to counteract the inflammatory processes both in arthritic fibroblast-like synoviocytes and chondrocytes, and in OA chondrocytes (Burguera et al. 2014; Fox et al. 2012; Ha et al. 2015; Kloesch et al. 2010; Kloesch et al. 2012a; Kloesch et al. 2012b; Li et al. 2013; Sieghart et al. 2015). Furthermore, OA cartilage might benefit from the exogenous supplementation of $\mathrm{H}_{2} \mathrm{~S}$ due to their 


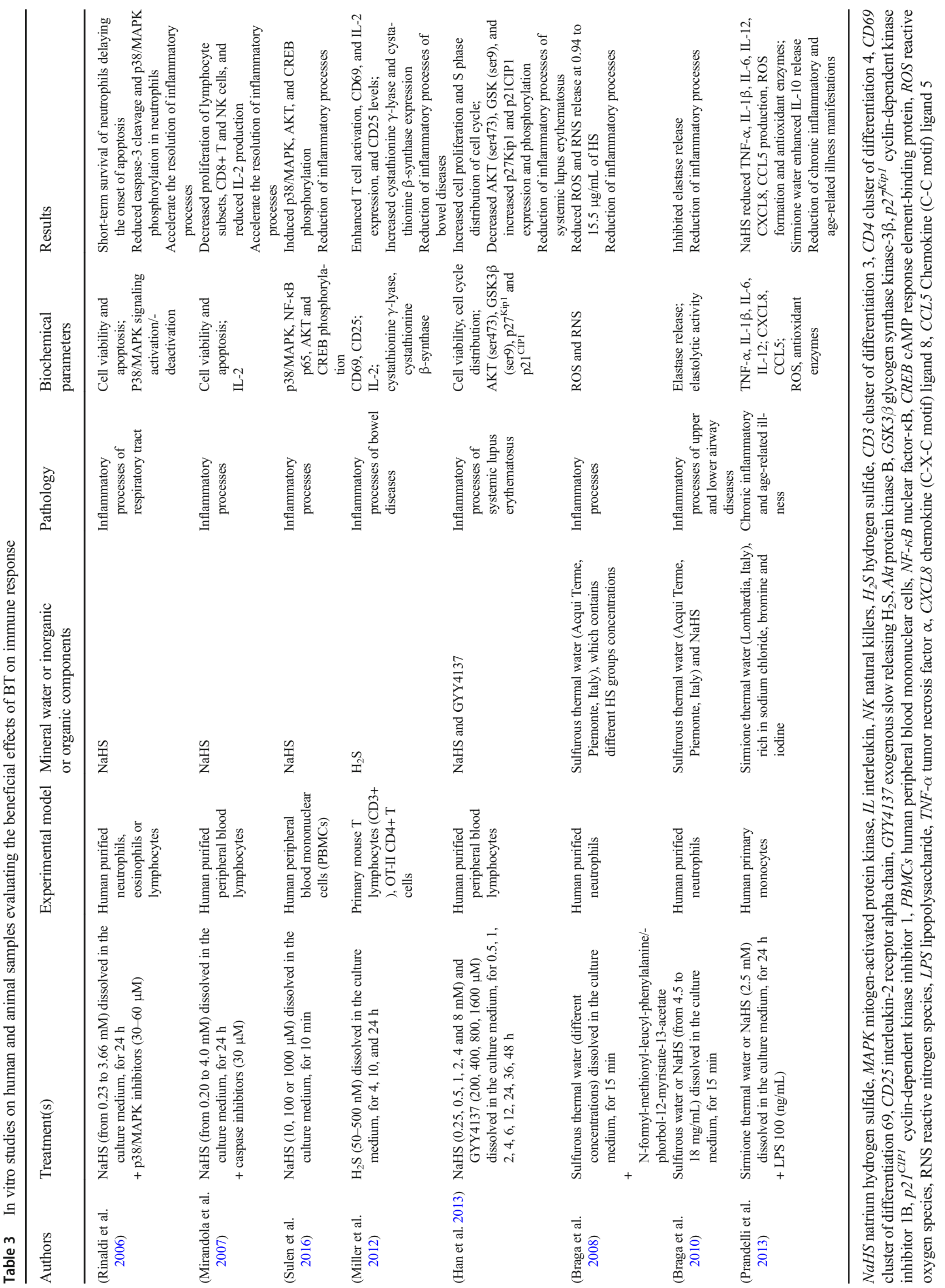


additive antioxidant and chondroprotective properties (Burguera et al. 2014; Fox et al. 2012; Ha et al. 2015; Li et al. 2013; Sieghart et al. 2015). The ability of $\mathrm{H}_{2} \mathrm{~S}$ donors to limit the oxidative stress damage was also confirmed in human primary or transformed cell lines of osteoblasts and osteoclasts (Gambari et al. 2014; Liu et al. 2017; Lv et al. 2017; Xu et al. 2011).

Moreover, the sulfide compounds seem to regulate inflammation and immune response in purified human peripheral blood neutrophils, eosinophils or lymphocytes (Braga et al. 2010; Miller et al. 2012; Mirandola et al. 2007; Rinaldi et al. 2006; Han et al. 2013; Sulen et al. 2016).

Finally, a limited number of studies attested the beneficial effect of different thermal mineral waters, tested as a whole, in human psoriatic keratinocytes, primary neutrophils and monocytes, and OA chondrocytes (Braga et al. 2008; Braga et al. 2010; Chiarini et al. 2006a; Chiarini et al. 2006b; Dal Pra et al. 2007; Fioravanti et al. 2013; Karagülle et al. 2018; Lee et al. 2012; Prandelli et al. 2013); furthermore, Gerencsér et al. (2019) confirmed the beneficial effects of organic rich extract of selected medicinal waters in protecting human keratinocytes from UV radiation-related DNA damage. The results demonstrated the anti-inflammatory and chondroprotective activities of thermal waters, as well as their antioxidant and immunomodulatory functions.

Taken together, these results demonstrated the simple, detailed and convenient analysis that can be made in in vitro testing, underlining the usefulness of these experimental studies in investigating how thermal waters, their mineral elements or their organic fraction are able to regulate cell metabolism under physiological or pathological stimuli. This approach allows to understand the specific effect of a mineral water or a particular inorganic or organic component, in terms of mechanisms of action and/or toxicity. Besides, the in vitro studies could be used to select the best required concentrations of a specific compound necessary for obtaining optimal biological benefits.

However, the validity of an in vitro study is conditioned by the adoption to the most appropriate experimental setup.

The choice of the suitable cell culture represents an important and essential key point to obtain the best experimental performance in terms of biological response. Although the high experimental repeatability and reproducibility of standardized and immortalized cell lines, primary cultures should be preferred to be carried out in in vitro studies since they are directly derived from the original tissue, and are heterogeneous and significant in terms of being the closest forms of the state of the cells that they represent in physiological or pathological tissues (Isyar et al. 2016). In any case, it is needed to keep in mind that primary cells have a limited lifespan and they stop dividing after a certain number of cell divisions and can be difficult to culture and maintain. The heterogeneity induced by the isolation of the cells from different donors could represent a source of experimental variability. Thus, the identification of the most suitable cell model for a specific pathological state, together with the maintenance of the optimal culture conditions, is required to obtain the best in vitro results, limiting possible bias (Khan and Gasser 2016).

Moreover, when the test is relative to a thermal water as a whole, it is needed to perform an adequate and accurate sterilization, without alter its physical-chemical characteristics, to avoid the possible contamination of the cultures, which can influence or interfere with the performance of the experiments (Lee et al. 2012).

However, the relevance of the preclinical tests needs to be considered with caution, since the changes that occur in the cells do not necessarily reflect in vivo conditions. Indeed, when cells are taken out from their natural environment and transferred into the culture, they are subtracted from a series of information or local and general interferences, and might lose their structural and functional characteristics (Cheleschi et al. 2017; De Palma et al. 2018; Fioravanti et al. 2010; Johnson et al. 2016; Montagne et al. 2017; Ogura et al. 2019; Pascarelli et al. 2015).

Furthermore, it is necessary to underline that the beneficial effects of BT in vivo are partially related to the temperature of the mineral water, while all the above-described in vitro studies have been performed at the physiological temperature of $37^{\circ} \mathrm{C}$, because supraphysiological temperatures could represent a source of bias in terms of cell viability and metabolism (Castander-Olarieta et al. 2019; Kaplan et al. 2003; Mead et al. 2012).

Another limitation of in vitro models in assessing the potential beneficial and/or toxic effects of thermal mineral waters or chemical or organic components is related to the purification and filtration procedures which could remove the natural spring water microbiome, recently considered to be responsible for some positive effects of BT in different diseases (Nicoletti et al. 2019; Pedron et al. 2019; Varga 2019).

The intent of this review served to summarize the current knowledge and advance about the in vitro research in the field of BT, discussing its strength and drawbacks. Taken together, the results of our analysis show that the in vitro studies take the advantage to represent simplified biological systems, useful to improve the knowledge about the potential mechanism of action of mineral water, tested as a whole or as singular mineral element or as organic fraction, at the molecular level. However, the usefulness of the culture models is limited by several sources of bias. Their validity is conditioned by a correct experimental procedure, which should take into consideration the particular and complex composition of mineral waters. Nowadays, analyzing the effects of the only inorganic composition of thermal waters is not enough, but it is necessary to perform a complex chemical analysis which should also consider their organic fraction that may play a role in the therapeutic efficacy or in other biological mechanisms as 
toxicity (Varga 2016). Another important critical point is related to the high heterogeneity existing among the available scientific studies that makes urgent the need to standardize the experimental procedures. Finally, the in vitro research does not allow to consider all the chemical, organic, and physical factors, as heat or microbiome influence, responsible for the clinical efficacy of BT. A possible solution to overcome some of these criticisms could be to investigate different treatment groups: (1) negative control, (2) positive control, (3) group of treatment with thermal water as a whole, (4) group of treatment with inorganic ingredients, and (5) group of treatment with organic extract from the original water (Varga 2016).

On the basis of these considerations, we would like to stimulate the following reflection: the studies on in vitro models could open the way to the scientific progress in the field of BT, but there is still a lot to do especially to engage the scientific community and to develop new research projects.

The future experimental strategies could also help us, in clinical practice, to identify the best personalized approach for each patient and for each pathological condition.

\section{Compliance with ethical standards}

Conflict of interest The authors declare that there is no conflict of interest.

\section{References}

Abu-al-Basal MA (2012) Histological evaluation of the healing properties of Dead Sea black mud on full-thickness excision cutaneous wounds in BALB/c mice. Pak J Biol Sci 15(7):306-315. https:// doi.org/10.3923/pjbs.2012.306.315

Antonelli M, Donelli D, Fioravanti A (2018) Effects of balneotherapy and spa therapy on quality of life of patients with knee osteoarthritis: a systematic review and meta-analysis. Rheumatol Int 38(10):18071824. https://doi.org/10.1007/s00296-018-4081-6

Bajgai J, Fadriquela A, Ara J, Begum R, Ahmed MF, Kim CS, Kim SK, Shim KY, Lee KJ (2017) Balneotherapeutic effects of high mineral spring water on the atopic dermatitis-like inflammation in hairless mice via immunomodulation and redox balance. BMC Complement Altern Med 17(1):481. https://doi.org/10.1186/s12906-017-1985-8

Braga PC, Sambataro G, Dal Sasso M, Culici M, Alfieri M, Nappi G (2008) Antioxidant effect of sulphurous thermal water on human neutrophil bursts: chemiluminescence evaluation. Respiration 75(2):193-201. https://doi.org/10.1159/000107976

Braga PC, Dal Sasso M, Culici M, Spallino A, Marabini L, Bianchi T, Nappi G (2010) Effects of sulphurous water on human neutrophil elastase release. Ther Adv Respir Dis 4(6):333-340. https://doi.org/ $10.1177 / 1753465810376783$

Britschka ZM, Teodoro WR, Velosa AP, de Mello SB (2007) The efficacy of Brazilian black mud treatment in chronic experimental arthritis. Rheumatol Int 28(1):39-45. https://doi.org/10.1007/s00296-0070371-0

Brosseau L, Robinson V, Léonard G, Casimiro L, Pelland L, Wells G, Tugwell P (2002) Efficacy of balneotherapy for rheumatoid arthritis: a meta-analysis. Phys Ther Rev 7:67-87. https://doi.org/10.1179/ 108331902125001879
Burguera EF, Vela-Anero A, Magalhães J, Meijide-Faílde R, Blanco FJ (2014) Effect of hydrogen sulfide sources on inflammation and catabolic markers on interleukin $1 \beta$-stimulated human articular chondrocytes. Osteoarthr Cartil 22(7):1026-1035. https://doi.org/ 10.1016/j.joca.2014.04.031

Burguera EF, Meijide-Failde R, Blanco FJ (2017) Hydrogen sulfide and inflammatory joint diseases. Curr Drug Targets 18(14):1641-1652. https://doi.org/10.2174/1389450117666160829112824

Carbajo JM, Maraver F (2017) Sulphurous mineral waters: new applications for health. Evid Based Complement Alternat Med 2017: 8034084. https://doi.org/10.1155/2017/8034084

Castander-Olarieta A, Montalbán IA, De Medeiros OE, Dell'Aversana E, D'Amelia L, Carillo P, Steiner N, Fraga HPF, Guerra MP, Goicoa T, Ugarte MD, Pereira C, Moncaleán P (2019) Effect of thermal stress on tissue ultrastructure and metabolite profiles during initiation of radiata pine somatic embryogenesis. Front Plant Sci 9:2004. https:// doi.org/10.3389/fpls.2018.02004

Cheleschi S, Cantarini L, Pascarelli NA, Collodel G, Lucherini OM, Galeazzi M, Fioravanti A (2015) Possible chondroprotective effect of canakinumab: an in vitro study on human osteoarthritic chondrocytes. Cytokine 71(2):165-172. https://doi.org/10.1016/j. cyto.2014.10.023

Cheleschi S, De Palma A, Pecorelli A, Pascarelli NA, Valacchi G, Belmonte G, Carta S, Galeazzi M, Fioravanti A (2017) Hydrostatic pressure regulates microRNA expression levels in osteoarthritic chondrocyte cultures via the $\mathrm{Wnt} / \beta$-catenin pathway. Int J Mol Sci 18(1):Pii: E133. https://doi.org/10.3390/ijms18010133

Cheleschi S, Giordano N, Volpi N, Tenti S, Gallo I, Di Meglio M, Giannotti S, Fioravanti A (2018) A complex relationship between visfatin and resistin and microRNA: an in vitro study on human chondrocyte cultures. Int J Mol Sci 19(12):pii: E3909. https://doi. org/10.3390/ijms19123909

Cheleschi S, Tenti S, Mondanelli N, Corallo C, Barbarino M, Giannotti S, Gallo I, Giordano A, Fioravanti A (2019a) MicroRNA-34a and microRNA-181a mediate visfatin-induced apoptosis and oxidative stress via NF-kB pathway in human osteoarthritic chondrocytes. Cells 8(8):pii: E874. https://doi.org/10.3390/cells8080874

Cheleschi S, Gallo I, Barbarino M, Giannotti S, Mondanelli N, Giordano A, Tenti S, Fioravanti A (2019b) MicroRNA mediate visfatin and resistin induction of oxidative stress in human osteoarthritic synovial fibroblasts via NF-KB pathway. Int J Mol Sci 20(20):pii: E5200. https://doi.org/10.3390/ijms20205200

Chiarini A, Dal Pra I, Pacchiana R, Menapace L, Zumiani G, Zanoni M, Armato U (2006a) Comano's (Trentino) thermal water interferes with the expression and secretion of vascular endothelial growth factor-A protein isoforms by cultured human psoriatic keratinocytes: a potential mechanism of its anti-psoriatic action. Int $\mathrm{J}$ Mol Med 18(1):17-25

Chiarini A, Dal Pra I, Pacchiana R, Zumiani G, Zanoni M, Armato U (2006b) Comano's (Trentino) thermal water interferes with interleukin-6 production and secretion and with cytokeratin-16 expression by cultured human psoriatic keratinocytes: further potential mechanisms of its anti-psoriatic action. Int J Mol Med 18(6):10731079

Ciani O, Pascarelli NA, Giannitti C, Galeazzi M, Meregaglia M, Fattore G, Fioravanti A (2017) Mud-bath therapy in addition to usual care in bilateral knee osteoarthritis: an economic evaluation alongside a randomized controlled trial. Arthritis Care Res (Hoboken) 69(7): 966-972. https://doi.org/10.1002/acr.23116

Collodel G, Fioravanti A, Pascarelli NA, Lamboglia A, Fontani V, Maioli M, Santaniello S, Pigliaru G, Castagna A, Moretti E, Iacoponi F, Rinaldi S, Ventura C (2013) Effects of regenerative radioelectric asymmetric conveyer treatment on human normal and osteoarthritic chondrocytes exposed to IL-1 $\beta$. A biochemical and morphological study. Clin Interv Aging 8:309-316. https://doi.org/10.2147/CIA. S42229 
Contoli M, Gnesini G, Forini G, Marku B, Pauletti A, Padovani A, Casolari P, Taurino L, Ferraro A, Chicca M, Ciaccia A, Papi A, Pinamonti S (2013) Reducing agents decrease the oxidative burst and improve clinical outcomes in COPD patients: a randomised controlled trial on the effects of sulphurous thermal water inhalation. ScientificWorldJournal 2013:927835. https://doi.org/10.1155/2013/ 927835

Cozzi F, Carrara M, Sfriso P, Todesco S, Cima L (2004) Antiinflammatory effect of mud-bath applications on adjuvant arthritis in rats. Clin Exp Rheumatol 22(6):763-766

Cozzi F, Ciprian L, Carrara M, Galozzi P, Zanatta E, Scanu A, Sfriso P, Punzi L (2018) Balneotherapy in chronic inflammatory rheumatic diseases-a narrative review. Int J Biometeorol 62(12):2065-2071. https://doi.org/10.1007/s00484-018-1618-z

Dal Pra I, Chiarini A, Pacchiana R, Zumiani G, Zanoni M, Armato U (2007) Comano's (Trentino) thermal water interferes with tumour necrosis factor-alpha expression and interleukin- 8 production and secretion by cultured human psoriatic keratinocytes: yet other mechanisms of its anti-psoriatic action. Int J Mol Med 19(3):373-379

De Palma A, Cheleschi S, Pascarelli NA, Giannotti S, Galeazzi M, Fioravanti A (2018) Hydrostatic pressure as epigenetic modulator in chondrocyte cultures: a study on miRNA-155, miRNA-181a and miRNA-223 expression levels. J Biomech 66:165-169. https://doi. org/10.1016/j.jbiomech.2017.10.044

Espejo-Antúnez L, Cardero-Durán MA, Garrido-Ardila EM, Torres-Piles S, Caro-Puértolas B (2013) Clinical effectiveness of mud pack therapy in knee osteoarthritis. Rheumatology (Oxford) 52(4):659-668. https://doi.org/10.1093/rheumatology/kes322

Fioravanti A, Collodel G, Petraglia A, Nerucci F, Moretti E, Galeazzi M (2010) Effect of hydrostatic pressure of various magnitudes on osteoarthritic chondrocytes exposed to IL-1beta. Indian J Med Res 132:209-217

Fioravanti A, Cantarini L, Guidelli GM, Galeazzi M (2011) Mechanisms of action of spa therapies in rheumatic diseases: what scientific evidence is there? Rheumatol Int 31(1):1-8. https://doi.org/10.1007/ s00296-010-1628-6

Fioravanti A, Lamboglia A, Pascarelli NA, Cheleschi S, Manica P, Galeazzi M, Collodel G (2013) Thermal water of Vetriolo, Trentino, inhibits the negative effect of interleukin $1 \beta$ on nitric oxide production and apoptosis in human osteoarthritic chondrocyte. $\mathrm{J}$ Biol Regul Homeost Agents 27(3):891-902

Fioravanti A, Bacaro G, Giannitti C, Tenti S, Cheleschi S, Gui Delli GM, Pascarelli NA, Galeazzi M (2015) One-year follow-up of mud-bath therapy in patients with bilateral knee osteoarthritis: a randomized, single-blind controlled trial. Int J Biometeorol 59(9):1333-1343. https://doi.org/10.1007/s00484-014-0943-0

Fioravanti A, Karagülle M, Bender T, Karagülle MZ (2017) Balneotherapy in osteoarthritis: facts, fiction and gaps in knowledge. Eur J Integrative Med 9:148-150

Fioravanti A, Manica P, Bortolotti R, Cevenini G, Tenti S, Paolazzi G (2018) Is balneotherapy effective for fibromyalgia? Results from a 6-month double-blind randomized clinical trial. Clin Rheumatol 37(8):2203-2212. https://doi.org/10.1007/s10067-018-4117-z

Forestier R, Desfour H, Tessier JM, Françon A, Foote AM, Genty C, Rolland C, Roques CF, Bosson JL (2010) Spa therapy in the treatment of knee osteoarthritis: a large randomised multicentre trial. Ann Rheum Dis 69(4):660-665. https://doi.org/10.1136/ard.2009. 113209

Forestier R, Erol-Forestier FB, Francon A (2017) Current role for spa therapy in rheumatology. Joint Bone Spine 84(1):9-13. https://doi. org/10.1016/j.jbspin.2016.05.003

Fortunati NA, Fioravanti A, Seri G, Cinelli S, Tenti S (2016) May spa therapy be a valid opportunity to treat hand osteoarthritis? A review of clinical trials and mechanisms of action. Int J Biometeorol 60(1): 1-8. https://doi.org/10.1007/s00484-015-1030-x
Fox B, Schantz JT, Haigh R, Wood ME, Moore PK, Viner N, Spencer JP, Winyard PG, Whiteman M (2012) Inducibile hydrogen sulphide synthesis in chondrocytes and mesenchymal progenitor cells: is H2S a novel cytoprotective mediator in the inflamed joint? J Cell Mol Med 16(4):896-910. https://doi.org/10.1111/j.1582-4934.2011. 01357.x

Gálvez I, Torres-Piles S, Ortega-Rincón E (2018) Balneotherapy, immune system, and stress response: a hormetic strategy? Int J Mol Sci 19(6): Pii: E1687. https://doi.org/10.3390/ijms19061687

Gambari L, Lisignoli G, Cattini L, Manferdini C, Facchini A, Grassi F (2014) Sodium hydrosulfide inhibits the differentiation of osteoclast progenitor cells via NRF2-dependent mechanism. Pharmacol Res 87:99-112. https://doi.org/10.1016/j.phrs.2014.06.014

Gerencsér G, Szabó I, Szendi K, Hanzel A, Raposa B, Gyöngyi Z, Varga C (2019) Effects of medicinal waters on the UV-sensitivity of human keratinocytes - a comparative pilot study. Int J Biometeorol 63(10): 1417-1423. https://doi.org/10.1007/s00484-019-01759-1

Gobbi G, Ricci F, Malinverno C, Carubbi C, Pambianco M, Gd P, Vitale M, Mirandola P (2009) Hydrogen sulfide impairs keratinocyte cell growth and adhesion inhibiting mitogen-activated protein kinase signaling. Lab Investig 89(9):994-1006. https://doi.org/10.1038/ labinvest.2009.61

Guidelli GM, Tenti S, De Nobili E, Fioravanti A (2012) Fibromyalgia syndrome and spa therapy: myth or reality? Clin Med Insights Arthritis Musculoskelet Disord 5:19-26. https://doi.org/10.4137/ CMAMD.S8797

Ha C, Tian S, Sun K, Wang D, Lv J, Wang Y (2015) Hydrogen sulfide attenuates IL-1 $\beta$-induced inflammatory signaling and dysfunction of osteoarthritic chondrocytes. Int J Mol Med 35(6):1657-1666. https://doi.org/10.3892/ijmm.2015.2183

Han Y, Zeng F, Tan G, Yang C, Tang H, Luo Y, Feng J, Xiong H, Guo Q (2013) Hydrogen sulfide inhibits abnormal proliferation of lymphocytes via AKT/GSK3 $\beta$ signal pathway in systemic lupus erythematosus patients. Cell Physiol Biochem 31(6):795-804. https://doi.org/ 10.1159/000350097

Hanks CT, Wataha JC, Sun Z (1996) In vitro models of biocompatibility: a review. Dent Mater 12(3):186-193. https://doi.org/10.1016/s01095641(96)80020-0

Hanzel A, Berényi K, Horváth K, Szendi K, Németh B, Varga C (2019) Evidence for the therapeutic effect of the organic content in Szigetvár thermal water on osteoarthritis: a double-blind, randomized, controlled clinical trial. Int J Biometeorol 63(4):449-458. https://doi.org/10.1007/s00484-019-01676-3

Huang A, Seité S, Adar T (2018) The use of balneotherapy in dermatology. Clin Dermatol 36(3):363-368. https://doi.org/10.1016/j. clindermatol.2018.03.010

Isyar M, Yilmaz I, Yasar Sirin D, Yalcin S, Guler O, Mahirogullari M (2016) A practical way to prepare primer human chondrocyte culture. J Orthop 13(3):162-167. https://doi.org/10.1016/j.jor.2016.03. 008

Johnson CI, Argyle DJ, Clements DN (2016) In vitro models for the study of osteoarthritis. Vet J 209:40-49. https://doi.org/10.1016/j.tvjl. 2015.07.011

Kaplan LD, Chu CR, Bradley JP, Fu FH, Studer RK (2003) Recovery of chondrocyte metabolic activity after thermal exposure. Am J Sports Med 31(3):392-398. https://doi.org/10.1177/03635465030310031101

Karagülle M, Karagülle MZ (2015) Effectiveness of balneotherapy and spa therapy for the treatment of chronic low back pain: a review on latest evidence. Clin Rheumatol 34(2):207-214. https://doi.org/10. 1007/s10067-014-2845-2

Karagülle MZ, Karagülle M, Kılıç S, Sevinç H, Dündar C, Türkoğlu M (2018) In vitro evaluation of natural thermal mineral waters in human keratinocyte cells: a preliminary study. Int J Biometeorol 62(9): 1657-1661. https://doi.org/10.1007/s00484-018-1565-8

Katz U, Shoenfeld Y, Zakin V, Sherer Y, Sukenik S (2012) Scientific evidence of the therapeutic effects of dead sea treatments: a 
systematic review. Semin Arthritis Rheum 2:186-200. https://doi. org/10.1016/j.semarthrit.2012.02.006

Khan M, Gasser S (2016) Generating primary fibroblast cultures from mouse ear and tail tissues. J Vis Exp 107. https://doi.org/10.3791/ 53565

Király M, Kővári E, Hodosi K, Bálint PV, Bender T (2019) The effects of Tiszasüly and Kolop mud pack therapy on knee osteoarthritis: a double-blind, randomised, non-inferiority controlled study. Int $\mathrm{J}$ Biometeorol:1-8. https://doi.org/10.1007/s00484-019-01764-4

Kloesch B, Liszt M, Broell J (2010) H2S transiently blocks IL-6 expression in rheumatoid arthritic fibroblast-like synoviocytes and deactivates p44/42 mitogen-activated protein kinase. Cell Biol Int 34(5): 477-484. https://doi.org/10.1042/CBI20090436

Kloesch B, Liszt M, Broell J, Steiner G (2011) Dimethyl sulphoxide and dimethyl sulphone are potent inhibitors of IL-6 and IL-8 expression in the human chondrocyte cell line C-28/I2. Life Sci 89(13-14): 473-478. https://doi.org/10.1016/j.lfs.2011.07.015

Kloesch B, Liszt M, Krehan D, Broell J, Kiener H, Steiner G (2012a) High concentrations of hydrogen sulphide elevate the expression of a series of pro-inflammatory genes in fibroblast-like synoviocytes derived from rheumatoid and osteoarthritis patients. Immunol Lett 141(2):197-203. https://doi.org/10.1016/j.imlet.2011.10.004

Kloesch B, Liszt M, Steiner G, Bröll J (2012b) Inhibitors of p38 and ERK1/2 MAPkinase and hydrogen sulphide block constitutive and IL- $1 \beta$-induced IL- 6 and IL-8 expression in the human chondrocyte cell line C-28/I2. Rheumatol Int 32(3):729-736. https://doi.org/10. 1007/s00296-010-1682-0

Lee HP, Choi YJ, Cho KA, Woo SY, Yun ST, Lee JT, Kim HJ, Lee KH, Kim JW (2012) Effect of spa spring water on cytokine expression in human keratinocyte HaCaT cells and on differentiation of CD4(+) T cells. Ann Dermatol 24(3):324-336. https://doi.org/10.5021/ad. 2012.24.3.324

Li L, Fox B, Keeble J, Salto-Tellez M, Winyard PG, Wood ME, Moore PK, Whiteman M (2013) The complex effects of the slow-releasing hydrogen sulfide donor GYY4137 in a model of acute joint inflammation and in human cartilage cells. J Cell Mol Med 17(3):365-376. https://doi.org/10.1111/jcmm.12016

Liu Y, Liu J, Li X, Wang F, Xu X, Wang C (2017) Exogenous H2S prevents high glucose-induced damage to osteoblasts through regulation of KATP channels. Biochimie 137:151-157. https://doi.org/ 10.1016/j.biochi.2017.03.009

Lv M, Liu Y, Xiao TH, Jiang W, Lin BW, Zhang XM, Lin YM, Xu ZS (2017) GYY4137 stimulates osteoblastic cell proliferation and differentiation via an ERK1/2-dependent anti-oxidant mechanism. Am J Transl Res 9(3):1183-1192

Marrazzo P, Angeloni C, Hrelia S (2019) Combined treatment with three natural antioxidants enhances neuroprotection in a SH-SY5Y 3D culture model. Antioxidants (Basel) 8(10):Pii: E420. https://doi. org/10.3390/antiox 8100420

Masiero S (2008) Thermal rehabilitation and osteoarticular diseases of the elderly. Aging Clin Exp Res 20(3):189-194. https://doi.org/10. 1007/bf03324772

Masiero S, Vittadini F, Ferroni C, Bosco A, Serra R, Frigo AC, Frizziero A (2018) The role of thermal balneotherapy in the treatment of obese patient with knee osteoarthritis. Int J Biometeorol 62(2):243-252. https://doi.org/10.1007/s00484-017-1445-7

Matsumoto S (2018) Evaluation of the role of balneotherapy in rehabilitation medicine. J Nippon Med Sch 85(4):196-203. https://doi.org/ 10.1272/jnms.JNMS.2018_85-30

Matsumoto H, Hagino H, Hayashi K, Ideno Y, Wada T, Ogata T, Akai M, Seichi A, Iwaya T (2017) The effect of balneotherapy on pain relief, stiffness, and physical function in patients with osteoarthritis of the knee: a meta-analysis. Clin Rheumatol 36(8):1839-1847. https:// doi.org/10.1007/s10067-017-3592-y

Mead RN, Ryu J, Liu S, Ge D, Lucas J, Savoie FH 3rd, You Z (2012) Supraphysiologic temperature enhances cytotoxic effects of bupivacaine on bovine articular chondrocytes in an in vitro study. Arthroscopy 28(3):397-404. https://doi.org/10.1016/j.arthro.2011. 08.308

Miller AJ, Spence JR (2017) In vitro models to study human lung development, disease and homeostasis. Physiology (Bethesda) 32(3): 246-260. https://doi.org/10.1152/physiol.00041.2016

Miller TW, Wang EA, Gould S, Stein EV, Kaur S, Lim L, Amarnath S, Fowler DH, Roberts DD (2012) Hydrogen sulfide is an endogenous potentiator of T cell activation. J Biol Chem 287(6):4211-4221. https://doi.org/10.1074/jbc.M111.307819

Mirandola P, Gobbi G, Sponzilli I, Pambianco M, Malinverno C, Cacchioli A, De Panfilis G, Vitale M (2007) Exogenous hydrogen sulfide induces functional inhibition and cell death of cytotoxic lymphocytes subsets. J Cell Physiol 213(3):826-833. https://doi.org/10. $1002 /$ jcp. 21151

Mirandola P, Gobbi G, Micheloni C, Vaccarezza M, Di Marcantonio D, Ruscitti F, de Panfilis G, Vitale M (2011) Hydrogen sulfide inhibits IL-8 expression in human keratinocytes via MAP kinase signaling. Lab Investig 91(8):1188-1194. https://doi.org/10.1038/labinvest. 2011.76

Montagne K, Onuma Y, Ito Y, Aiki Y, Furukawa KS, Ushida T (2017) High hydrostatic pressure induces pro-osteoarthritic changes in cartilage precursor cells: a transcriptome analysis. PLoS One 12(8): e0183226. https://doi.org/10.1371/journal.pone.0183226

Morer C, Roques CF, Françon A, Forestier R, Maraver F (2017) The role of mineral elements and other chemical compounds used in balneology: data from double-blind randomized clinical trials. Int $\mathbf{J}$ Biometeorol 61(12):2159-2173. https://doi.org/10.1007/s00484017-1421-2

Naumann J, Sadaghiani C (2014) Therapeutic benefit of balneotherapy and hydrotherapy in the management of fibromyalgia syndrome: a qualitative systematic review and meta-analysis of randomized controlled trials. Arthritis Res Ther 16(4):R141. https://doi.org/10.1186/ $\operatorname{ar} 4603$

Nicoletti G, Saler M, Tresoldi MM, Faga A, Benedet M, Cristofolini M (2019) Regenerative effects of spring water-derived bacterial lysates on human skin fibroblast in in vitro culture: preliminary results. J Int Med Res 47(11):5777-5786. https://doi.org/10.1177/ 0300060519880371

Ogura T, Minas T, Tsuchiya A, Mizuno S (2019) Effects of hydrostatic pressure and deviatoric stress on human articular chondrocytes for designing neo-cartilage construct. J Tissue Eng Regen Med 13(7): 1143-1152. https://doi.org/10.1002/term.2863

Ozkurt S, Dönmez A, Zeki Karagülle M, Uzunoğlu E, Turan M, Erdoğan $\mathrm{N}$ (2012) Balneotherapy in fibromyalgia: a single blind randomized controlled clinical study. Rheumatol Int 32(7):1949-1954. https:// doi.org/10.1007/s00296-011-1888-9

Pascarelli NA, Collodel G, Moretti E, Cheleschi S, Fioravanti A (2015) Changes in ultrastructure and cytoskeletal aspects of human normal and osteoarthritic chondrocytes exposed to interleukin- $1 \beta$ and cyclical hydrostatic pressure. Int J Mol Sci 16(11):26019-26034. https://doi.org/10.3390/ijms161125936

Pedron R, Esposito A, Bianconi I, Pasolli E, Tett A, Asnicar F, Cristofolini M, Segata N, Jousson O (2019) Genomic and metagenomic insights into the microbial community of a thermal spring. Microbiome 7(1):8. https://doi.org/10.1186/s40168-0190625-6

Péter I, Jagicza A, Ajtay Z, Boncz I, Kiss I, Szendi K, Kustán P, Németh BV (2017) Balneotherapy in psoriasis rehabilitation. In Vivo 31(6): $1163-1168$

Prandelli C, Parola C, Buizza L, Delbarba A, Marziano M, Salvi V, Zacchi V, Memo M, Sozzani S, Calza S, Uberti D, Bosisio D (2013) Sulphurous thermal water increases the release of the antiinflammatory cytokine IL-10 and modulates antioxidant enzyme activity. Int J Immunopathol Pharmacol 26(3):633-646. https://doi. org/10.1177/039463201302600307 
Rinaldi L, Gobbi G, Pambianco M, Micheloni C, Mirandola P, Vitale M (2006) Hydrogen sulfide prevents apoptosis of human PMN via inhibition of p38 and caspase 3. Lab Investig 86(4):391-397. https://doi.org/10.1038/labinvest.3700391

Santos I, Cantista P, Vasconcelos C (2016) Balneotherapy in rheumatoid arthritis-a systematic review. Int J Biometeorol 60(8):1287-1301. https://doi.org/10.1007/s00484-015-1108-5

Scheich B, Vincze P, Szőke É, Borbély É, Hunyady Á, Szolcsányi J, Dénes Á, Környei Z, Gaszner B, Helyes Z (2017) Chronic stressinduced mechanical hyperalgesia is controlled by capsaicinsensitive neurones in the mouse. Eur J Pain 21(8):1417-1431. https://doi.org/10.1002/ejp.1043

Shams K, Kurowska-Stolarska M, Schütte F, Burden AD, McKimmie CS, Graham GJ (2018) MicroRNA-146 and cell trauma downregulate expression of the psoriasis-associated atypical chemokine receptor ACKR2. J Biol Chem 293(8):3003-3012. https://doi.org/ 10.1074/jbc.M117.809780

Sieghart D, Liszt M, Wanivenhaus A, Bröll H, Kiener H, Klösch B, Steiner G (2015) Hydrogen sulphide decreases IL-1 $\beta$-induced activation of fibroblast-like synoviocytes from patients with osteoarthritis. J Cell Mol Med 19(1):187-197. https://doi.org/10.1111/jcmm. 12405

Sulen A, Gullaksen SE, Bader L, McClymont DW, Skavland J, Gavasso S, Gjertsen BT (2016) Signaling effects of sodium hydrosulfide in healthy donor peripheral blood mononuclear cells. Pharmacol Res 113(Pt A):216-227. https://doi.org/10.1016/j.phrs.2016.08.018

Szabó C (2007) Hydrogen sulphide and its therapeutic potential. Nat Rev Drug Discov 6(11):917-935. https://doi.org/10.1038/nrd2425

Szabó I, Varga C (2019) Finding possible pharmacological effects of identified organic compounds in medicinal waters (BTEX and phenolic compounds). Int J Biometeorol:1-7. https://doi.org/10.1007/ s00484-019-01808-9. [Epub ahead of print]

Tefner IK, Németh A, Lászlófi A, Kis T, Gyetvai G, Bender T (2012) The effect of spa therapy in chronic low back pain: a randomized controlled, single-blind, follow-up study. Rheumatol Int 32(10):31633169. https://doi.org/10.1007/s00296-011-2145-y

Tékus V, Horváth Á, Hajna Z, Borbély É, Bölcskei K, Boros M, Pintér E, Helyes Z, Pethö G, Szolcsányi J (2016) Noxious heat threshold temperature and pronociceptive effects of allyl isothiocyanate (mustard oil) in TRPV1 or TRPA1 gene-deleted mice. Life Sci 154:6674. https://doi.org/10.1016/j.lfs.2016.04.030

Tékus V, Borbély É, Kiss T, Perkecz A, Kemény Á, Horváth J, Kvarda A, Pintér E (2018) Investigation of Lake Hévíz mineral water balneotherapy and Hévíz mud treatment in murine osteoarthritis and rheumatoid arthritis models. Evid Based Complement Alternat Med 2018:4816905. https://doi.org/10.1155/2018/4816905

Tenti S, Cheleschi S, Galeazzi M, Fioravanti A (2015) Spa therapy: can be a valid option for treating knee osteoarthritis? Int J Biometeorol 59(8):1133-1143. https://doi.org/10.1007/s00484-014-0913-6
Varga C (2010) Problems with classification of spa waters used in balneology. Health 2:1260-1263. https://doi.org/10.4236/health.2010. 211187

Varga C (2012a) Balneoprevention: new approaches. Int J Biometeorol 56(1):195-197. https://doi.org/10.1007/s00484-010-0377-2

Varga C (2012b) Volatile organics in thermal spa waters: active ingredientsor environmental toxicants? Thermae Spa Med 1(2):1-8

Varga C (2016) On the proper study design applicable to experimental balneology. Int J Biometeorol 60(8):1307-1309. https://doi.org/10. 1007/s00484-015-1113-8

Varga C (2019) To treat or not to treat? Misbeliefs in spa water disinfection. Int J Biometeorol 63(8):1135-1138. https://doi.org/10.1007/ s00484-019-01722-0

Varga C, László M, Gerencsér G, Gyöngyi Z, Szendi K (2015) Natural UV-protective organic matter in thermal water. $J$ Photochem Photobiol B 144:8-10. https://doi.org/10.1016/j.jphotobiol.2015. 01.007

Vela-Anero Á, Hermida-Gómez T, Gato-Calvo L, Vaamonde-García C, Díaz-Prado S, Meijide-Faílde R, Blanco FJ, Burguera EF (2017) Long-term effects of hydrogen sulfide on the anabolic-catabolic balance of articular cartilage in vitro. Nitric Oxide 70:42-50. https:// doi.org/10.1016/j.niox.2017.08.004

Viegas J, Esteves AF, Cardoso EM, Arosa FA, Vitale M, Taborda-Barata L (2019) Biological effects of thermal water-associated hydrogen sulfide on human airways and associated immune cells: implications for respiratory diseases. Front Public Health 7:128. https://doi.org/ 10.3389/fpubh.2019.00128

Wallace JL, Wang R (2015) Hydrogen sulfide-based therapeutics: exploiting a unique but ubiquitous gasotransmitter. Nat Rev Drug Discov 14(5):329-345. https://doi.org/10.1038/nrd4433

Xu ZS, Wang XY, Xiao DM, Hu LF, Lu M, Wu ZY, Bian JS (2011) Hydrogen sulfide protects MC3T3-E1 osteoblastic cells against $\mathrm{H} 2 \mathrm{O} 2$-induced oxidative damage-implications for the treatment of osteoporosis. Free Radic Biol Med 50(10):1314-1323. https://doi. org/10.1016/j.freeradbiomed.2011.02.016

Yücesoy H, Geçmen İ, Adıgüzel T, Karagülle M, Karagülle MZ (2019) Efficacy of balneological outpatient treatment (hydrotherapy and peloidotherapy) for the management of chronic low back pain: a retrospective study. Int J Biometeorol 63(3):351-357. https://doi. org/10.1007/s00484-018-01668-9

Zivná H, Maric L, Gradosová I, Svejkovská K, Hubená S, Zivný P (2012) The effect of mud-bath therapy on bone status in rats during adjuvant subchronic arthritis. Acta Medica (Hradec Kralove) 55(3):133137. https://doi.org/10.14712/18059694.2015.51

Publisher's note Springer Nature remains neutral with regard to jurisdictional claims in published maps and institutional affiliations. 